\title{
Organic fertilization and botanical insecticides to control two-spotted spider mite in strawberry
}

\author{
Fertilização orgânica e inseticidas botânicos para controle do ácaro \\ rajado em morango
}

\section{Camila Regina Marques-Francovig ${ }^{\mathrm{I}}$ Adriana Yatie Mikami $^{\mathrm{I}}$ Viviane Dutra $^{\mathrm{I}}$ Mateus Gimenez Carvalho ${ }^{\mathrm{I}}$ Bruno Picareli ${ }^{\mathrm{I}}$ Maurício Ursi Ventura ${ }^{\mathrm{I}}$}

\begin{abstract}
Strawberry fields receive several pesticides spraying and residues in fruits are recurrent. Development and application of methods that avoid applying pesticides mostly during fructification period are imminent needs. Comparison of population of twosppoted spider mite (TSSM) Tetranychus urticae Koch. in organic and mineral fertilized plants (as used by growers) and treated with alternative products were done. Plants were grown in vessels in a greenhouse infested with local population of TSSM. Extracts of Tephrosia voggeli (Hook), neem oil (Azadirachta indica A. Juss.), and lime sulfur were applied three times against TSSM in ten days intervals. Assessments were done three times after each spraying. Interaction between fertilization and spraying alternatives was also assessed but was not significant. TSSM population was about $44 \%$ lesser in organic fertilized plants than those in inorganic fertilized. T. voggeli extracts reduced in large amounts TSSM; neem oil reduced in some assessments and an intermediate reduction was found for sulfur lime. Organic fertilization and T. voggeli extracts are potential strategies to manage TSSM and additional studies are proposed to enable wide utilization.
\end{abstract}

Key words: integrated pest management, botanical insecticide, organic agriculture.

\section{RESUMO}

Lavouras de morango recebem várias aplicações de agrotóxicos e resíduos nos frutos são recorrentes. O desenvolvimento e a aplicação de métodos de manejo que evitem a aplicação de pesticidas, principalmente durante o período de frutificação, é uma necessidade iminente. Compararam-se as populações do ácaro rajado Tetranychus urticae Koch. em plantas adubadas com fertilizantes orgânicos e minerais (como o usados por produtores) e tratadas com produtos alternativos. As plantas foram cultivadas em vasos, em casa de vegetação infestada de população local do ácaro. Extratos de Tephrosia voggelii (Hook), óleo de nim (Azadirachta indica A. Juss.) e calda sulfocálcica foram pulverizados três vezes em intervalos de 10 dias. As avaliações foram realizadas três vezes após cada pulverização. A interação entre a fertilização e produtos alternativos em pulverização foi também avaliada, mas não foi significativa. A população do ácaro foi cerca de $44 \%$ menor em plantas fertilizadas com fertilizante orgânico do que aquelas com fertilizante mineral. Extrato de T. voggelii reduziu em grande quantidade a população do ácaro; o óleo de nim reduziu em algumas avaliações e redução intermediária foi observada com calda sulfocálcica. Adubação orgânica e extrato de T. voggeli são estratégias potenciais para manejar a população de ácaros e estudos adicionais são propostos para permitir ampla utilização.

Palavras-chave: manejo integrado de pragas, inseticidas botânicos, agricultura orgânica.

\section{INTRODUCTION}

Strawberry plants (Fragaria $x$ ananassa Duch.) are damaged by several pests and diseases that occur mostly during flowering and fructification period. Growes spray chemicals to manage them and consequently residues of pesticides have been recurrent in surveys carried out during several years in Brazil (ANVISA, 2010). Presently this is a serious public concern and the development of strategies to manage strawberry pests avoiding pesticide utilization is a priority.

Among the arthropods, the two-spotted spider mite (TSSM) Tetranychus urticae (Koch) is a key pest, that attacks leaves and green fruits, reducing fruit weight and yield (MORAES \& FLECHTMANN, 2008). In general, TSSM is controled by using spraying synthetic miticides. Several spraying can

\footnotetext{
IDepartamento de Agronomia, Universidade Estadual de Londrina (UEL), Campus Universitário, CP 6001, 86051-970, Londrina, PR, Brasil. E-mail: mventura@uel.br.*Autor para correspondência. 
be done during the production cycle, what increases costs of production, TSSM resistance and causes pollution (SATO et al., 2005; PERES et al., 2005).

In organic production, cultural practices are important preventive strategies against pests and are the first phase in the management of arthropods and phytopathogens. In this way, adequate soil management including fertilization, as well as other cultural practices may be used to contribute to pest reduction in the field (ZEHNDER et al., 2007). An appreciable amount of studies have characterized reduction of pests in plants due to equilibrated fertilization mainly when organic matter is included (ZEHNDER et al., 2007). In addition to preventive strategies, curative options must be available to reduce insects in the field when just preventive strategies are not enough to keep mite populations bellow damaging levels. Lime sulfur is a former option to control mites and have been used mostly in organic production (CHAGAS et al., 2001; VENZON et al., 2006).

Botanicals insecticides can play an important role in pest management for organic production mostly in minor areas crops although after generalization of the usage of synthetic chemical insecticides, they have been relegated to a trivial position (ISMAN, 2005). Neem (Azadirachta indica A. Juss) and Tephrosia spp. (Fabaceae ) plant derivates are widely used worldwide (ISMAN, 2005). Previous results have showed effect of formulations of neem and rotenone against TSSM (CASTAGNOLI et al., 2005).

The goal of this study was to investigate preventive and curative strategies on TSSM population management in greenhouse. The eventual interaction of these strategies was also assessed. Fertilization methods used by organic and conventional growers (organic X inorganic) were compared. The control of the TSSM by spraying neem oil, T. vogelii (Hook) extracts and lime sulfur was also assessed.

\section{MATERIAL AND METHODS}

A greenhouse experiment was carried out in the Agronomy Departament at Universidade Estadual de Londrina, Londrina, Paraná, Brazil from May to June, 2011. Strawberry plantings (cv. 'Oso Grande') originated from growers in Pinhalão, PR, were obtained from EMATER Institute. The experiment was settled in a completely randomized design in $2 \times 5$ factorial with four replicates. The first factor was fertilization using the organic and mineral levels. The second one was the spraying treatments: water (control); neutral biodegradable detergent (NBD) (Alpes, Química Alpina S.A., Apucarana, Paraná) $1.0 \%$; oil of seeds of
T. vogelii $2.0 \%$ plus DNB 1.0\% (oil emulsifier); neem oil 2.0\% (NeemAzal-T/S, Trifolio-M GmbH, Lahnau, Alemanha) containing $10 \mathrm{~g} \mathrm{l}^{-1}$ of azadiractina $\mathrm{A}$ and sulfur lime $2.0 \%$. The extraction of $\boldsymbol{T}$. vogelii was carried out using methyl acetate in a Soxhlet apparatus according to MIKAMI (2011).

Plantings were transferred from the field to vessels containing $4 \mathrm{~kg}$ of ravine soil (poor soil with trace levels of organic matter) on May 6. Fertilization recommendations were chosen from well established extension services in regions of strawberry production. Mineral fertilization was used according to RONQUE (2010) and organic fertilization was used according to SOUZA \& RESENDE (2006).

Local TSSM population infested strawberry plants without need for additional infestation. The first spraying was done 28 days after planting and repeated two times, each 10 days using hand sprayers in both abaxial and adaxial leaves surfaces. Spray was done until runoff of the solution, with a flow rate of $90 \mathrm{ml} \mathrm{min}{ }^{-1}$, tapered spray nozzle, spraying angle of 45 and a distance of $10 \mathrm{~cm}$ from the surface of the plant. Mite assessments were done at three, five and ten days after spraying. An area of $1.5 \mathrm{~cm}^{2}$ per leaf of surveyed plants was randomly chosen and assessed using a 20 times hand magnifier. Four samples were taken in the upper third of each four plants. Analysis of variance was performed. Means were compared using Tukey test $(\mathrm{P}<0.05)$ when isolated factors or interactions were significant.

\section{RESULTS AND DISCUSSION}

No significant interaction between fertilization and spraying factors was found for all assessments. An overview of the results is shown in figure 1. It is possible to see that the adding effects of organic fertilizantion together with the botanicals $\boldsymbol{T}$. vogelii extracts or neem oil kept TSSM populations are close to economic damage threshold. However, for mineral fertilized plants, only in the second and third assessements this occurred with $\boldsymbol{T}$. vogelii extracts only.

\section{Fertilization}

In the three first assessments that occurred with three, five and ten days after spraying (DAS) (31, 33 and 38 days after planting-DAP), similar populations of the TSSM in organic and mineral fertilization were found (Table 1). However, after the second spraying, from 41 to 58 DAP, in general, the number of mites was greater in plants with mineral than organic fertilization (Table 1). When all assessment was considered, means $44.4 \%$ more mites were found 


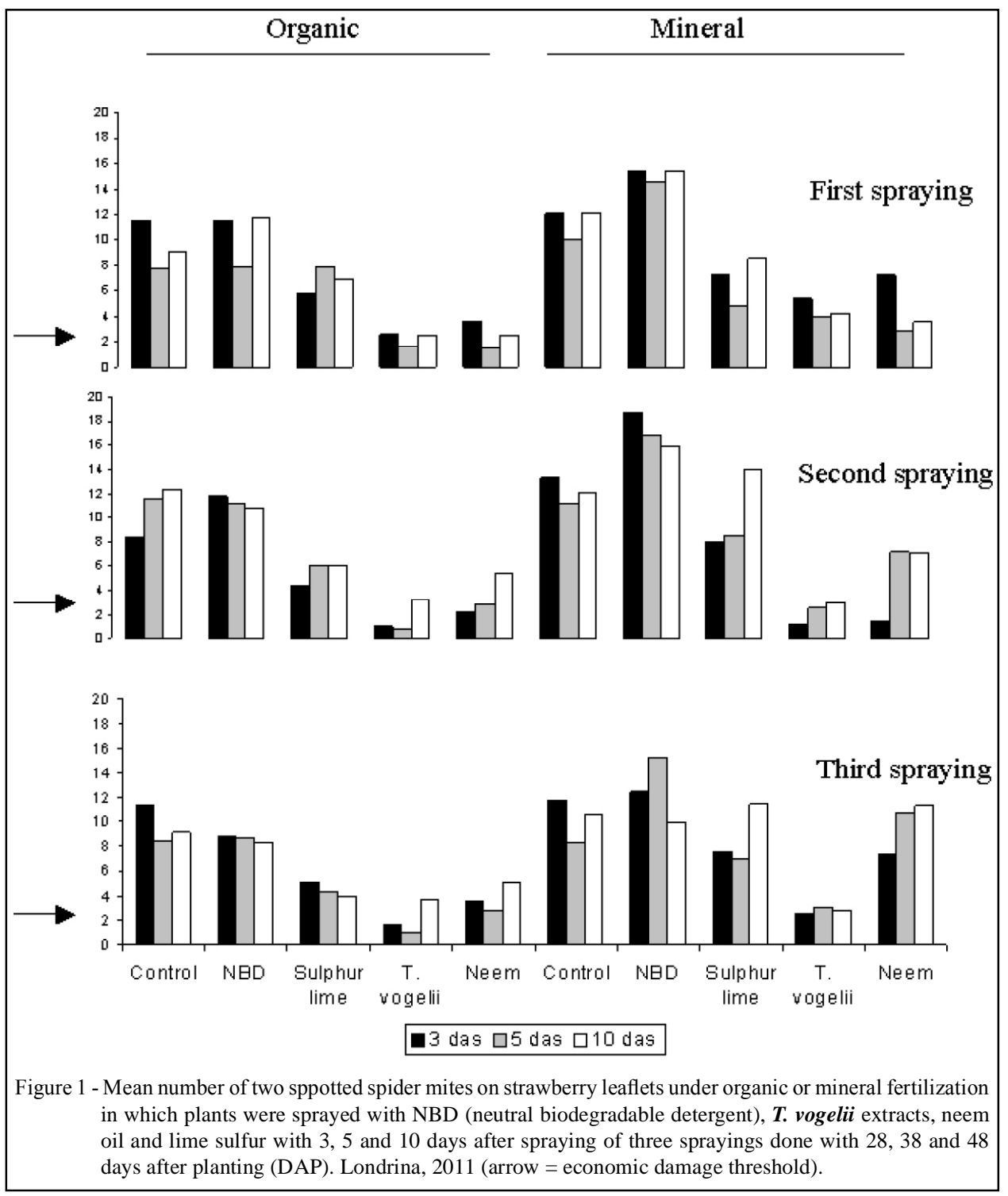

in mineral fertilized plants than in organic ones. These results corroborate previous studies in which mineral fertilization, mostly $\mathrm{N}$, has been reported as responsible for increasing populations of TSSM. For exemple, life-table parameters (reproductive rate and intrinsic rate of increase) were previously affected by $\mathrm{N}$ fertilization and leaves contents (SUSKI \& BADOWSKA, 1975; JESIOTR et al., 1979). In apple plants, insect fecundity increased 10 times when a $\mathrm{N}$ dosage two times greater the recommended rate was used. High $\mathrm{N}$ levels also improved TSSM populations in radish plants (MELLORS \& PROPTS, 1983). Reduction of the $\mathrm{N}$ fertilization in rose plants was proposed as a strategy to manage TSSM and reduced two times the nymphs and eggs without a significant decrease in yield (CHOW et al., 2009).
Lower infestations by other taxa also have been found in organic systems when compared with conventional ones mostly when associated with application of high levels of N. The populations of the planthopper Sogatella furcifera (Horvath) (Hemiptera: Delphacidae) were lower in organic fields than in conventional ones (KAJIMURA, 1995). Populations of the trips Frankliniella occidentalis (Pergande) (Thysanoptera: Thripidae) were higher in those plants with high levels of $\mathrm{N}$ fertilization (BRODBECK et al., 2001). Besides the TSSM, the mealy bug (Pseudococcus sp.) and aphid Myzus persicae (Sulz.) were reduced on plants in greenhouse when vermicompost were included in the medium bedding plant (ARANCON et al., 2007). Some reasons have been proposed to explain the lower incidence of

Ciência Rural, v.44, n.11, nov, 2014. 
Table 1 - Mean number $\left( \pm\right.$ SEM) of the two-sppotted spider mites in samples $\left(1.5 \mathrm{~cm}^{2}\right.$ strawberry leaves $)$ with three, five and 10 days after each one of three sprayings done with 28,38 and 48 days after planting (DAP) with alternative products in organic or mineral fertilized plants in greenhouse. Londrina, 2011.

\begin{tabular}{|c|c|c|c|c|c|c|c|}
\hline \multirow{2}{*}{$\begin{array}{l}\text { Days after } \\
\text { spraying }\end{array}$} & \multicolumn{2}{|c|}{---------- Fertilization ---------- } & \multirow[b]{2}{*}{ Control } & \multirow[b]{2}{*}{$\mathrm{NBD}^{2}$} & \multirow[t]{2}{*}{ aying treatm } & \multirow[b]{2}{*}{ Neem oil } & \multirow[b]{2}{*}{$\mathrm{SL}^{4}$} \\
\hline & Organic & Mineral & & & & & \\
\hline \multicolumn{8}{|c|}{ - } \\
\hline 3 & $7.0(0.2) \mathrm{A}$ & $8.4(0,2) \mathrm{A}$ & $12.1(0.4) b$ & $13.8(0,5) \mathrm{b}$ & $4.0(0.1) \mathrm{a}$ & $2.3(0,1) \mathrm{a}$ & $6.5(0,2) a b$ \\
\hline 5 & $5.2(0.1) \mathrm{A}$ & $7.5(0.2) \mathrm{A}$ & $10.5(0.4) b$ & $8.5(0.2) b$ & $2.4(0.2) \mathrm{a}$ & $2.0(0.2) \mathrm{a}$ & $6.2(0.4) \mathrm{ab}$ \\
\hline 10 & $6.4(0.2) \mathrm{A}$ & $9.0(0.3) \mathrm{A}$ & $13.3(0.4) b$ & $11.0(0.5) b$ & $3.0(0.2) \mathrm{a}$ & $3.1(0.2) \mathrm{a}$ & $8.2(0.4) a b$ \\
\hline 3 & $5.4(0.2) \mathrm{A}$ & $8.5(0.3) \mathrm{B}$ & $11.0(0.3) b c$ & $15.2(0.5) \mathrm{c}$ & $1.0(0.1) \mathrm{a}$ & $1.9(0.1) \mathrm{a}$ & $6.1(0.2) \mathrm{b}$ \\
\hline 5 & $6.4(0.2) \mathrm{A}$ & $9.3(0.3) \mathrm{B}$ & $11.6(0.4) \mathrm{cd}$ & $14.1(0.4) \mathrm{d}$ & $0.8(0.4) \mathrm{a}$ & $5.0(0.4) \mathrm{a}$ & $7.3(0.2) b c$ \\
\hline 10 & $7.5(0.1) \mathrm{A}$ & $10.2(0.2) \mathrm{B}$ & $12.1(0.2) \mathrm{c}$ & $13.1(0.4) \mathrm{c}$ & $2.9(0.2) \mathrm{a}$ & $6.1(0.1) a b$ & $9.9(0.4) b c$ \\
\hline 3 & $6.2(0.2) \mathrm{A}$ & $8.2(0.4) \mathrm{A}$ & $\begin{array}{l}11.8(0.4) \text { bc } \\
11 .-- \text { Third sp }\end{array}$ & $\begin{array}{c}n g(48 \text { DAP }) \\
10.8(0.6) \mathrm{c}\end{array}$ & $2.1(0.4) \mathrm{a}$ & $5.2(0.4) \mathrm{ab}$ & $6.4(0.4) b c$ \\
\hline 5 & $4.9(0.1) \mathrm{A}$ & $9.0(0.2) \mathrm{B}$ & $8.3(0.5) b$ & $11.9(0.6) b$ & $1.9(0.3) \mathrm{a}$ & $6.9(0.4) a b$ & $5.4(0.4) a b$ \\
\hline 10 & $5.8(0.2) \mathrm{A}$ & $9.3(0.2) \mathrm{B}$ & $9.9(0.3) b$ & $9.2(0.4) a b$ & $3,1(0.5) \mathrm{a}$ & $8.3(0.5) a b$ & $8.1(0.4) a b$ \\
\hline
\end{tabular}

${ }^{1}$ Means followed by the same letter in the line did not differ when using Tukey test $(\mathrm{P}<0.05)$ (Upper case letter for fertilization method and lower case for spraying treatments).

${ }^{2}$ Neutral biodegradable detergents.

${ }^{3}$ Tephrosia vogelii extracts.

${ }^{4}$ Sulfur lime.

arthropod pests in organics systems, compared to conventional agriculture under applications of widespectrum chemical insecticides (ZEHNDER et al., 2007). One of the probable explanations is the gradual liberation of nutrients in organic fertilized plants. On the other hand, the fertilization with soluble fertilizers mostly containing nitrogen formulations unbalances the nutrients in the plant tissues producing free amino acids what favors pest incidence (ALTIERI \& NICHOLLS, 2003) including mites (TULISALO, 1971). The improvement of soil microbiota when organic fertilization is done could also upgrade plant resistance (ALTIERI \& NICHOLLS, 2003). ARANCON et al. (2007) reported reduction of TSSM, when vermicompost was included in the bedding plant medium and attributed the arthropod reduction on plants by the changes in the form of $\mathrm{N}$, slower release rates of mineral nutrients and particularly by the increasing production of phenolics.

Spraying alternative pesticides

T. voggelii extract was the most effective curative treatment against TSSM in all assessments achieved (Table 1 and Figure 1). The neem oil also reduced populations in the first and second assessments. Intermediate values were found for the lime sulfur treatment.
Deguelin (the major constituent), tephrosin and three other minor rotenoids were previously characterized in methyl acetate fractions of $\boldsymbol{T}$. vogelii (MIKAMI, 2011) and probably are the responsable for the TSSM mortality. The activity found in this study corroborates previous studies on $T$. vogelii extracts. Mortality and repellency of Sitophilus zeamais (Motsch.) (Coleoptera: Curculionidae) was found for T. vogelii dusts when added to maize grains (OGENDO et al., 2003). Hexanic extracts also provoked mortality and decrease of oviposition, reducing the subsequent generations of Acanthoscelides obtectus (Say.) (Coleoptera: Bruchidae), Callosobruchus maculatus (Fabricius) (Coleoptera: Bruchidae) and C. chinensis (L.) (Coleoptera: Bruchidae) (KOONA $\&$ DORN, 2005). The same effects were found for $S$. zeamais in stored maize grains which were superior than those obtained from neem extracts (KOONA et al., 2007). Extracts of shoots, cortex and roots of $\boldsymbol{T}$. vogelii (methanol, ether, cloroform and water) were applied on several species of cattle ticks in laboratory and caused $100 \%$ of mortality (MATOVU \& OLILA, 2007). Besides mortality, another probable action of the $\boldsymbol{T}$. voggeli extracts was antifeedant since it was previously related for Tephrosia spp. This was true for extractions of T. elata (Deflers) that characterized tephrosin which showed activity against Spodoptera 
exempta (Walk.) (Lepdoptera: Noctuidae); isopongaflavone against Maruca testulalis (Geyer) (Lepidoptera: Pyralidae) and Eldana saccharina (Walk.) (Lepidoptera: Pyralidae) and rotenone against $S$. exempta, E. saccharina and M. testulalis. The same effects were seen for $\boldsymbol{T}$. emoroides (A. Rich.) extracts against spotted cereal stem borer (Chilo partellus Swinhoe) (MACHOCHO, 1995).

Reduction of TSSM population after neem derivates usage as reported here was attributed mostly for mortality, repellency, reduction of the oviposition and decrease in egg eclosion (DIMETRY et al., 1993; BRITO et al., 2006; CASTIGLIONI et al., 2002). Although a greater concentration of the neem oil (2\%) was used in our study than the majority of previous ones, an apparent reduction of the neem efficiency was observed after second and third spraying (Figure 1). In general, the results show close to $100 \%$ of reduction of TSSM population. It is probably that the conditions under which experiments are carried out and the neem formulations characteristics may influence the results. The results were conducted during a more extensive period (three sprayings) and directly in the plants. In general, the majority of the studies were conducted just after one spraying in leaf discs (DIMETRY et al., 1993; BRITO et al., 2006, CASTIGLIONI et al., 2002). In the same way when neem was applied directly on plants (carrots, Daucus carota L.) TSSM mortality was in shorter levels (DUCHOVSKIENE et al., 2008).

Although sulfur lime has been suggested as toxic to TSSM (BEERS et al., 2009) and Polyphagotarsonemus latus (Banks) (Acari: Tarsonemidae) (VENZON et al., 2006), in the present study populations in the treated plants were intermediate between $\boldsymbol{T}$. vogelii extracts treated plants and control. In addition to this lack of efficiency against the pest, sulfur-based products have been shown in detrimental to predatory mites in laboratory experiments (BEERS et al., 2009) what can put in doubt the usage of these compounds to manage TSSM.

Besides the reduction of the TSSM, organic fertilization was also been shown as important to reduce nematodes (ARANCON et al., 2002) and soilborne diseases in strawberry fields (CHAOUI et al., 2002). In addition, in recent studies more antioxidant substances have been found in organic cultivated tomato fruits than in conventional ones (MITCHELL et al., 2007). Extracts of organic-produced strawberry fruits had a higher antiproliferative activity for cancer cells at the highest concentration than the conventionally grown ones, and this was suggested as a probable higher content of secondary metabolites
(OLSSON et al., 2006). Yields of organically cultivated strawberries have been eventually lower than those of conventional fields (GLIESSMAN et al., 2006), although long-term studies have showed growing levels of soil fertility and yields in organic systems (HERENCIA et al., 2007).

T. vogelii extracts showed potential to be used to control TSSM in strawberries. In general, rotenoids are known as short time effective against pests in the field due to the sun light degradation (CHENG et al., 1972). In crops that are sprayed, harvested and consumed in natura in a feel days, this trait is also favorable since residues can be eliminated or even minimized. Botanicals are special candidates to be used in integrated pest management in organics in small area crops, in which strawberry is included. In such cases, commercial or home-made formulations could be used. However, additional studies must be developed before recommendation and implementation of $\boldsymbol{T}$. vogelii extracts in farm condition, i.e., formulation procedures, toxicity for mammals, residues in fruits, selectivity to natural enemies etc.

Lower populations of the TSSM were found in organic fertilized strawberry plants than those fertilized with inorganic. T. vogelii extracts reduced strongly populations of TSSM; neem oil reduced in the first assessments but efficiency was reduced in the remaining assessments; lime sulfur was intermediate between control treatment and $\boldsymbol{T}$. vogelii sprayed plants.

\section{REFERENCES}

AGÊNCIA NACIONAL DE VIGILÂNCIA SANITÁRIA (ANVISA). Programade análise de resíduos de agrotóxicos em alimentos. Brasília, 2010. 26p.

ALTIERI, M.A.; NICHOLLS, C.A. Soil fertility management and insect pests: harmonizing soil and plant health in agroecosystems. Soil Tillage Res, v.72, p.203-211, 2002. Available from: <http:// dx.doi.org/10.1016/S0167-1987(03)00089-8>. Accessed: nov. 15, 2011. doi: 10.1016/S0167-1987(03)00089-8.

ARANCON, N.Q. et al. Management of plant parasitic nematode populations by use of vermicomposts. Proc of the Brighton Crop Protection Conference, v.45, p.18-21, 2002.

ARANCON, N.Q. et al.m Supression of two-spotted spider mite (Tetranychus urticae), mealy bugs (Peseudococcus) and aphid (Myzus persicae) populations and damage by vermicomposts. Crop Prot, v.26, p.26-39, 2007. Available from:.<http://dx.doi. org/10.1016/j.cropro.2006.03.013>. Accessed: may 12, 2-14. doi 10.1016/j.cropro.2006.03.013.

BEERS, E.H. et al. Lethal, sublethal, and behavioral effects of sulfur-containing products in bioassays of three species of orchard mites. J Econ Entomol, v.102, p.324-335, 2009.

Ciência Rural, v.44, n.11, nov, 2014. 
BRITO, H.M. et al. Toxicidade de Natuneem sobre Tetranychus urticae Koch (Acari: Tetranychidae) e ácaros predadores da família Phytoseiidae. Cienc Agrotecnol, v.30, p.685-691, 2006

BRODBECK, B. et al. Flower nitrogen status and populations of Frankliniella occidentalis feeding on Lycopersicon esculentum. Entomol Exp Appl, v.99, p.165-172, 2001. Available from: <http://dx.doi.org/10.1046/j.1570-7458.2001.00814.x> Accessed may 12, 2-14. doi. 10.1046/j.1570-7458.2001.00814.x.

CASTIGLIONI, E. et al. Evaluación del efecto tóxico de extractos acuosos y derivados de meliáceas sobre Tetranychus urticae (Koch) (Acari, Tetranychidae). Agrociência, v.6, p.75-82, 2002.

CASTAGNOLI, M. et al. Toxicity of some insecticides to Tetranychus urticae, Neoseiulus californicus and Tydeus californicus. BioControl, v.50, p.611-622, 2005.

CHAGAS, P.R.R. et al. Efficiency of lime sulfur in the control of the two-spotted mite in papaya in conventional and organic (Bokashi-EM) systems. In: CONFERENCE ON KYUSEI NATURE FARMING, 6., 2001, Pretoria. Proceedings... Japan/ Atami: INFRC, 2001. p.255-258

CHAOUI, H. et al. Suppression of the plant diseases, Pythium (damping off), Rhizoctonia (root rot) and Verticillium (wilt) by Vermicomposts. Proc of Brighton Crop Protection ConferencePests and Diseases, v.II, n.8B-3, p.711-716, 2002

CHENG, H.M. et al. Rotenone decomposition. J Agric Food Chem, v.20, p.850-856, 1972.

CHOW, A. et al. Reducing fertilization for cut roses: effect on crop productivity and twospotted spider mite abundance, distribution and management. J Econ Entomol, v.102, p.1896-1907, 2009.

DIMETRY, N.Z. et al. Biological activity of two neem seed kernel extracts against the twospotted spider mite Tetranychus urticae Koch. J Appl Entomol, v.116, p.308-312, 1993.

DUCHOVSKIENE, L. et al. The effect of biopesticide NeemAzal$\mathrm{T} / \mathrm{S}$ on the Tetranychus urticae Koch. in carrot seed plants under greenhouse conditions. Scientific works of the Lithuanian Institute of Horticulture and Lithuanian University of Agriculture, Sodininkyste ir daržininkyste, v.27, n.4, p.177-182, 2008.

GLIESSMAN, S.R. et al. Conversion to organic strawberry management changes ecological processes. Calif Agric, v.50, p.24-31, 1996. Available from: <http://ucce.ucdavis.edu/files/ repositoryfiles/ca5001p24-69742.pdf>. Accessed: jan, 152012.

HERENCIA, J.F. et al. Comparison between organic and mineral fertilization for soil fertility levels, crop macronutrient concentrations, and yield. Agron J, v.99, p.973-983, 2007.

ISMAN, M.B. Problems and opportunities for the commercialization of botanical insecticides. In: ROGER, C.R. et al. (Eds). Biopesticides of plant origin. Paris: Lavosier, 2005. 546p. p.283-291

JESIOTR, L.J. et al. Food quality influences on a spider mite population. In: RODRIGUEZ J.G. (Ed.). Recent advances in acarology. New York: Academic, 1979. 650p. p.169-189.

KAJIMURA, T. Effect of organic rice farming on planthoppers: reproduction of white backed planthopper,
Sogatella furcifera (Homoptera: Delphacidae). Res Popul Ecol, v.37, p.219-224, 1995.

KOONA, P.; DORN, S. Extracts from Tephrosia vogelii for the protection of stored legume seeds against damage by three bruchid species. Ann Appl Biol, v.147, p.43-48, 2005. Available from: <http://dx.doi.org/10.1111/j.1744-7348.2005.00006.x> Accessed: may 12, 2-14. doi. 10.1111/j.1744-7348.2005.00006.x.

KOONA, P. et al. Hexane extracts from Tephrosia vogelii Hook. f. protect stored maize against the weevil Sitophilus zeamais Motschulsky (Coleoptera: Curculionidae). Entomol Sci, v.10, p.107-111, 2007.

MACHOCHO, A.K. et al. Three new Bavonoids from the roo of Tephrosia emoroides and their antifeedant activity against the larvae of the spotted stalk borer Chilo partellus Swinhoe. Int $\mathbf{J}$ Pharm, v.33, p.222-227, 1995.

MATOVU, H; OLILA, D. Acaricidal activity of Tephrosia vogell extracts on nimph and adult ticks. Int J Trop Med, v.2, p.83-88, 2007.

MELLORS, W.K.; PROPTS, S.E. Effects of fertilizer level, fertility balance, and soil moisture on the interaction of the twospotted spider mites (Acarina: Tetranychidae) with radish plants. Environ Entomol, v.12, p.1236-1244, 1983.

MIKAMI, A. Mortalidade do percevejo Euschistus heros (f.) (Hemiptera: Pentatomidae) provocada por extratos de sementes de Tephrosia sp. (Fabaceae) e de anonáceas. 2011. 49f. Tese (Doutorado em Agronomia, Fitossanidade - UEL Londrina, PR.

MITCHELL, A.E. et al. Ten-year comparison of the influence of organic and conventional crop management practices on the content of flavonoids in tomatoes. J Agric Food Chem, v.55, p.6154-6159, 2007.

MORAES, G.J.; FLECHTMANN, C.H.W. Manual de acarologia: acarologia básica e ácaros de plantas cultivadas no Brasil. Ribeirão Preto, Holos, 2008. 288p.

OLSSON, M.E. et al. Antioxidant levels and inhibition of cancer cell proliferation in vitro by extracts from organically and conventionally cultivated strawberries. J Agrc Food Chem, v.54, p.1248-1255, 2006.

OGENDO, J.O. et al. Comparison of toxic and repellent effects of Lantana camara L. with Tephrosia vogelii Hook and a synthetic pesticide against Sitophilus zeamais Motschulsky (Coleoptera: Curculionidae) in stored maize grain. Insect Sci App, v.23, p.127-135, 2003. Available from <http://dx.doi.org/10.1111/ j.1744-7348.2005.00006.x.> Accessed: September 12, 2012. doi. 10.1111/j.1744-7348.2005.00006.x

PERES, F. et al. Challenges in the study of human and environmental contamination by pesticides. Cie. Saúde Coletiva, v.10, p.27-37, 2005

RONQUE, E. A cultura do morangueiro. Curitiba: Ministério de Desenvolvimento Agrário, 2010. 52p

SATO, M.E. et al. Abamectin resistance in Tetranychus urticae Koch (Acari: Tetranychidae): selection, cross-resistance and stability of resistance. Neotrop Entomol, v.34, p.1-8, 2005. 
SOUZA, J.L.; RESENDE, P. Manual de horticultura orgânica. Viçosa, Aprenda Fácil, 2006. 560p.

SUSKI, Z.W.; BADOWSKA, T. Effect of the host plant nutrition on the population of the two spotted spider mite, Tetranychus urticae Koch (Acarina, Tetranychidae). Ekol Pol Ser A, v.23, p.185-209, 1975.

TULISALO, U. Free and bound amino acids of three host plants species and various fertilizer treatment saffecting the fecundity of two-spotted spider mite, Tetranychus urticae Koch. Ann Entomol Fenn, v.37, p.155-163, 1971.

VENZON, M. et al. Potential of alternative pesticides for control of broad mite on chili pepper "Malagueta". Hort Bras, v.24, p.224-227, 2006.

ZEHNDER, G. et al. Arthropod pest management in organic crops. Annu Rev Entomol, v.52, p.57-80, 2007. 